\title{
Ecological Assessment of Heavy metals in Sediments of the Farahabad Region (Iran)
}

\author{
Abdol Ghaffar Ebadi*, Hikmat Hisoriev \\ Institute of Botany, Plant Physiology and Genetics, Tajik Academy of Sciences, \\ Dushanbe, Tajikistan
}

Received: 14 June 2017

Accepted: 3 September 2017

\begin{abstract}
The current study assessed trace metal contamination in sediments using different types of indices. Six heavy metals such as $\mathrm{Cu}, \mathrm{Zn}, \mathrm{Mg}, \mathrm{Fe}, \mathrm{Mn}$, and $\mathrm{Ca}$ were investigated in the sediments of the Farah Abad region in Iran. The metals concentration was found in the range of 15, 16, 59, 770, 3.2 , and $14.5 \mathrm{mg} / \mathrm{kg}$ for $\mathrm{Cu}, \mathrm{Zn}, \mathrm{Mn}, \mathrm{Fe}, \mathrm{Mg}$, and $\mathrm{Ca}$, respectively. The enrichment factor was lower than unity, indicating the absence of anthropogenic influence. The contamination factor and geo-accumulation indices for $\mathrm{Cu}, \mathrm{Zn}, \mathrm{Mn}, \mathrm{Mg}$, and $\mathrm{Ca}$ were $<1$ and $<0$, respectively, indicating no pollution at all from the selected metals, whereas $\mathrm{CF}$ and Igeo values for Fe were significantly greater than 5 , suggesting a high enrichment from anthropogenic sources. The potential ecological risk index for $\mathrm{Cu}$ and $\mathrm{Zn}$ showed a value of 2.376, indicating low ecological risk to the selected sites from the accumulation of trace metals.
\end{abstract}

Keywords: metal, ecological assessment, sediments, Farahabad Region, Iran

\section{Introduction}

The rate of rapid development in the coastal regions of the world have resulted in environmental pollution [1]. Increased concentrations of metals in aquatic ecosystems has now become a global problem [1-2]. Sediments act as a reservoir for metal accumulation, which poses a serious threat to adjacent ecosystems [3]. Metals released into aquatic ecosystems are adsorbed by suspended sediments and settle [4]. This results in a lower concentration of heavy metals in the water column and makes the surface sediments a reservoir for particulate-bound pollutants

*e-mail: dr_ebadi2000@mail.ru
[5]. Benthic fauna depend on bottom sediments as their habitat and food source [6]. The accumulated heavy metals in sediments are released into the water column by certain variables like redox potential, altering $\mathrm{pH}$, mobilization of benthic biota, and sediment re-suspension [7]. Thus, particulate-bound metals are a source of contamination to aquatic ecosystems. Due to processes like bioaccumulation and bio-concentration, the effects of heavy metals may be detected on land through the food web [8].

Metals are toxic owing to their bio-magnification and non-biodegradability in the food chain [9]. Discharge of heavy metals from natural and anthropogenic sources ultimately may accumulate in sediments [5]. The biotas attached to sediments are at high risk to metal exposure, 
which ultimately makes its way into the food chain $[5,10]$. Thus it is important to constantly monitor the enrichment pattern in order to evaluate the natural and anthropogenic sources of metal pollution [11].

Sediments can be used as an indicator to monitor pollution level of aquatic ecosystems [3, 12]. Extensive literature is available to estimate sediment contamination of aquatic ecosystems [13]. This includes sediment quality guidelines [14-15], enrichment factor (EF) [16], contamination factor (CF) and contamination degree (Cd) [17], modified degree of contamination ( $\mathrm{mCd}$ ) [16], pollution load index (PLI) [18], and contamination severity index and assessment of potential ecological risk [17].

The Farahabad region in northern Iran is a tourist hub. Its beaches attract a number of tourists every year. Owing to anthropogenic activities, it is necessary to monitor its pollution status. None of the study has yet been conducted to evaluate the metal pollution of the selected sites. Therefore, the aim of this study is to evaluate the concentration of selected metals in the study area and apply various indices to determine the potential ecological risk and degree of contamination.

\section{Experimental}

\section{Study Area}

The Farah Abad Region in Mazandaran Province is an important tourist site located in northern Iran. Figure 1 depicts the Farah Abad Region and points of sample collection.

\section{Sample Collection}

Surface sediments were collected from four sampling sites. The whole area was partitioned into four sampling stations. At each sampling site, four sediment samples
(5 $\mathrm{cm}$ of surface sediment) were taken in a covered area of $16 \mathrm{~m}^{2}$ using a Peterson grab sampler. A composite sediment sample was made for each station using a plastic spoon. The sediment samples were placed in polyethylene bottles, temporarily stored in a cooler at less than $4^{\circ} \mathrm{C}$, and then transported to a laboratory [19-20].

\section{Chemical Treatment}

For acid digestion, each sediment sample (1.0 g) was digested in an acid-cleaned vessel of Teflon that contained $5 \mathrm{ml}$ of nitric acid (ultra-pure) and $2 \mathrm{ml}$ conc. hydrofluoric acid (ultra-pure). For each batch of digestion a blank sample was prepared containing the same ratio of acids without sediment samples. The prepared digested sediment samples were then passed through Whatman No.1 filter paper and stored at $4^{\circ} \mathrm{C}$ for instrumental analysis [19, 21].

\section{Instrumentation}

Samples of sediment were then quantified by atomic absorption spectrophotometry for the selected six metals, including manganese $(\mathrm{Mn})$, copper $(\mathrm{Cu})$, magnesium $(\mathrm{Mg})$, zinc $(\mathrm{Zn})$, iron $(\mathrm{Fe})$, and calcium $(\mathrm{Ca})$. For accuracy the calibration line method was employed by maintaining optimum analytical conditions (Kimbrough and Lauenstein 2007). All the standard solutions and reagents were of analytical grade with a high degree of purity $(>99.99 \%)$. The accuracy of the method was maintained by comparing with the standard reference material (MESS-3) [22].

\section{Assessing Sediment Contamination}

For determining the contaminants at any site, it should be compared to any other pre-anthropogenic reference site. The comparative proportion would show the degree of contamination. A number of methods have been developed

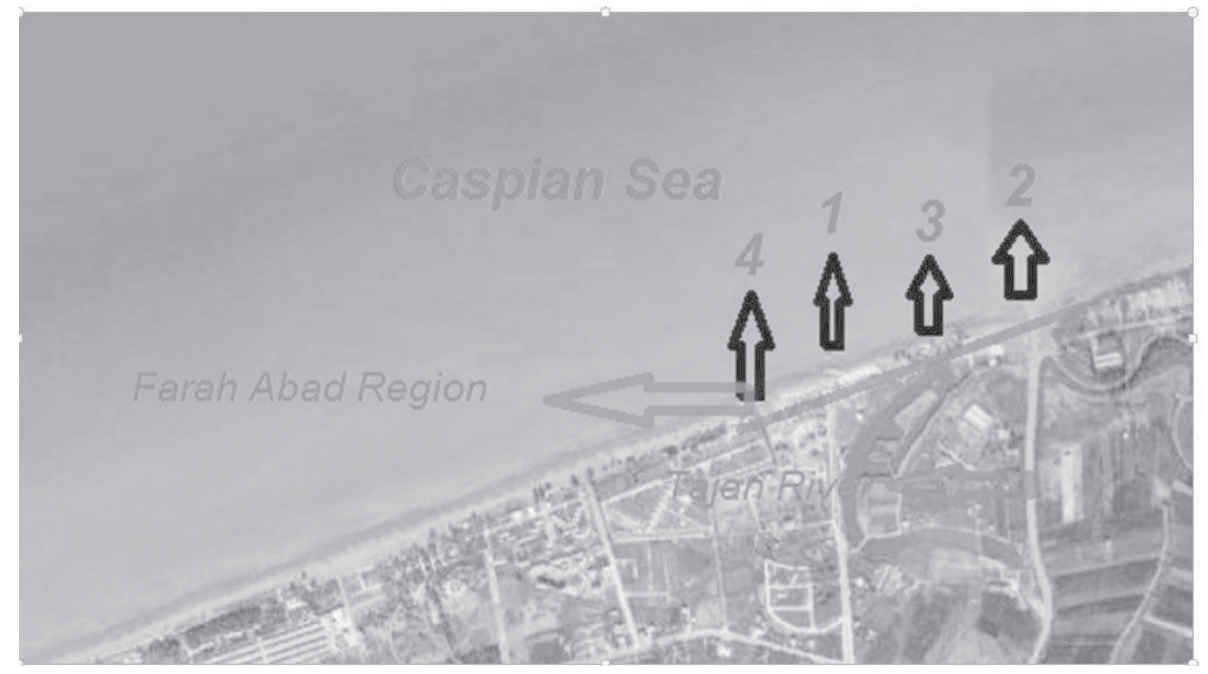

Fig. 1. Sampling points of Farah Abad region sediment. 
to monitor the heavy metal pollution by comparing it to reference values [17]. As there is no pre-industrial data of the study area, the average shale-certified values [16] were used as background values [22]. The enrichment factor, Geoaccumulation index, contamination factor, and modified degree of contamination all were based on comparison of a local reference site with respect to the average shale values [16, 23].

\section{Enrichment Factor (EF)}

To monitor the anthropogenic impact on sediments, a common approach called enrichment factor is commonly used to compare the contaminated site with the background reference site [23]. The advantage of enrichment factor is its normalization factor. This factor normalizes the value of measured heavy metals with respect to the benchmark or reference values. This can be done by multiplying both values to those of $\mathrm{Fe}$ or Al. Various studies have reported different elements for normalization factor. This study used $\mathrm{Fe}$ as a normalization factor owing to its constraint properties of anthropogenic addition to sediments and its high natural concentration [16]. The enrichment factor can be calculated as follows:

$$
E F=\frac{M_{x} \times F e_{b}}{M_{b} \times F e_{x}}
$$

...where EF is the enrichment factor, and $\mathrm{M}_{\mathrm{x}}$ and $\mathrm{Fe}_{\mathrm{x}}$ are the contaminated sample concentrations of sediment and normalization element, respectively. $\mathrm{M}_{\mathrm{b}}$ and $\mathrm{Fe}_{\mathrm{b}}$ are the reference site values for sediments and normalization element, respectively.

\section{Pollution Load Index (PLI)}

The pollution load index was suggested by the Irish Estuarine Research Group and mainly was used for heavy metal contamination by a number of studies [18]. The pollution load index requires the contamination factors that can be derived by comparing the level of contaminated sediments to the reference value. The sum of contamination factors for various metals was used to find out the pollution index of each polluted site. This index helps to categorize the polluted sites into various contaminated zones and then can be compared. The pollution index can be described as the nth root of various contamination factors [18]. The equation is as follows:

$$
\begin{gathered}
P L I=\sqrt[n]{C_{f}^{1}} \times C_{f}^{2} \times C_{f}^{3} \times \ldots \times C_{f}^{n} \\
C_{f}^{n}=\frac{C_{s}^{i}}{C_{n}^{i}}
\end{gathered}
$$

...where PLI is pollution load index and $\mathrm{C}_{\mathrm{f}}^{\mathrm{n}}$ is the contamination factor. $\mathrm{C}_{\mathrm{S}}^{\mathrm{i}}$ is heavy metal concentration in contaminated sediments and $\mathrm{C}_{\mathrm{n}}^{\mathrm{i}}$ is heavy metal concentration of reference site.

$$
\text { Geoaccumulation Index }\left(I_{g e o}\right)
$$

Based on some studies, we used a common method for determining sediment quality (Table 1). Although it is also based on polluted site to that of reference site, this model also shows us numerical values to designate the quality of sediments. The Müller equation uses factor 1.5 to normalize the variation of natural geochemical differences between the reference and potential site of contamination [24]:

$$
\text { Igeo }=\log _{2} \frac{C_{n}}{1.5 B_{n}}
$$

...where $\mathrm{C}_{\mathrm{n}}$ is the element concentration in sediments while $B_{n}$ is the benchmark value or reference value.

\section{Modified Degree of Contamination $(m C d)$}

For ecological risk assessment, Hakanson proposed an ecological risk index model. As a requirement value for that model, Hakanson also proposed a proportionate called degree of contamination [17]. The degree of contamination is only limited to seven metals for their contamination. One cannot add additional elements for their degree of contamination. Thus, there was a need to design a model that entails all the metals. Abrahim (2005) modified and generalized the Hakanson model called modified degree of contamination. This index takes the sum of all contamination factors and divides it by the total number of pollutants. The mean values of modified degree of contamination were divided into seven classes based on degree of contamination [16]. The modified equation is as follows:

$$
m C d=\frac{\sum_{i}^{n} C_{f}^{i}}{n}
$$

...where $\mathrm{n}$ stands for total number of elements analyzed and $\mathrm{C}_{\mathrm{f}}^{\mathrm{i}}$ Stands for contamination factor (Table 2).

Table 1. Geoaccumulation Index.

\begin{tabular}{|c|c|c|}
\hline $\begin{array}{c}\text { Igeo } \\
\text { value }\end{array}$ & $\begin{array}{c}\text { Igeo } \\
\text { class }\end{array}$ & Level of contamination \\
\hline$>5$ & 6 & Extremely contaminated \\
\hline $4-5$ & 5 & Strongly to extremely contaminated \\
\hline $3-4$ & 4 & Strongly contaminated \\
\hline $2-3$ & 3 & Moderately to strongly contaminated \\
\hline $1-2$ & 2 & Moderately contaminated \\
\hline $0-1$ & 1 & $\begin{array}{c}\text { Uncontaminated to moderately } \\
\text { contaminated }\end{array}$ \\
\hline 0 & 0 & Uncontaminated \\
\hline
\end{tabular}


Table 2. Modified degree of contamination.

\begin{tabular}{|c|c|}
\hline$(\mathrm{mCd})$ values & Contamination Level \\
\hline $\mathrm{mCd}<1.5$ & Nil to very low degree of contamination \\
\hline $1.5 \leq \mathrm{mCd}<2$ & Low degree of contamination \\
\hline $2 \leq \mathrm{mCd}<4$ & Moderate degree of contamination \\
\hline $4 \leq \mathrm{mCd}<8$ & High degree of contamination \\
\hline $8 \leq \mathrm{mCd}<16$ & Very high degree of contamination \\
\hline $16 \leq \mathrm{mCd}<32$ & Extremely high degree of contamination \\
\hline $\mathrm{mCd} \geq 32$ & Ultra high degree of contamination \\
\hline
\end{tabular}

\section{Potential Ecological Risk Index}

The ecological risk index was designed by Hakanson [17]. The risk index is to find out the risk associated to the ecological health owing to the entrance of pollutants that will ultimately make its way into the food chain. The concentration of metals in contaminated sites were compared to the average shale values to find out the contamination factor by the following equation.

$$
C_{f}=\frac{C_{0-1}}{C_{n}}
$$

The sum of contamination factors were used to find out the degree of contamination by using the following equation:

$$
\mathrm{E}_{\mathrm{r}}^{\mathrm{i}}=\mathrm{T}_{\mathrm{r}}^{\mathrm{i}} \times \mathrm{C}_{\mathrm{f}}^{\mathrm{i}}
$$

The ecological risk factor $\mathrm{E}_{\mathrm{r}}^{\mathrm{i}}$ was calculated by multiplying toxic risk factor already given by Hakanson to the contamination factor. The toxic risk factor of heavy metals is shown in Table 3 .

The equation for risk factor was determined as follows:

$$
\mathrm{E}_{\mathrm{r}}^{\mathrm{i}}=\mathrm{T}_{\mathrm{r}}^{\mathrm{i}} \times \mathrm{C}_{\mathrm{f}}^{\mathrm{i}}
$$

The sum of risk factor values was used to determine the potential ecological risk index based on the following equation:

$$
\mathrm{RI}=\sum_{\mathrm{i}=1}^{\mathrm{n}} \mathrm{E}_{\mathrm{r}}^{\mathrm{i}}=\sum_{\mathrm{r}}^{\mathrm{n}} \mathrm{T}_{\mathrm{r}}^{\mathrm{i}} \times \mathrm{C}_{\mathrm{f}}^{\mathrm{i}}
$$

...where $\mathrm{E}_{\mathrm{r}}^{\mathrm{i}}$ stands for potential ecological risk factor, $\mathrm{T}_{\mathrm{r}}^{\mathrm{i}}$

Table 3. Toxic risk factor for heavy metals developed by Hakanson.

\begin{tabular}{|c|c|}
\hline Heavy Metals & $\mathrm{T}_{\mathrm{r}}^{\mathrm{i}}$ \\
\hline $\mathrm{Cu}$ & 5 \\
\hline $\mathrm{Zn}$ & 1 \\
\hline
\end{tabular}

Table 4. RI classification (Hakanson 1980).

\begin{tabular}{|c|c|}
\hline RI values & Risk intensity \\
\hline$<150$ & Low ecological risk \\
\hline $150 \leq \mathrm{RI}<300$ & Moderate ecological risk \\
\hline $300 \leq \mathrm{RI}<600$ & Considerable ecological risk \\
\hline$<600$ & Very high ecological risk \\
\hline
\end{tabular}

stands for toxic response factor of heavy metal I, and $\mathrm{C}_{\mathrm{f}}^{\mathrm{i}}$ stands for contamination of heavy metal .

Potential ecological risk index (RI) is classified into four different classes shown in Table 4:

\section{Results and Discussion}

Table 5 shows heavy metals concentrations in four sites. The summarized values, average concentrations, and average shale or background values were also delineated in the table. The highest concentration $(779 \mathrm{mg} / \mathrm{kg})$ of Fe was detected at site 4 and the highest concentration of $\mathrm{Mn}(59 \mathrm{mg} / \mathrm{kg})$ was detected at site 1 . The concentration for $\mathrm{Cu}$ was in the range of 13 to $15 \mathrm{mg} / \mathrm{kg}$ and $\mathrm{Zn}$ ranged 15 to $16 \mathrm{mg} / \mathrm{kg}$. The values of Fe were in the range 762 to $779 \mathrm{mg} / \mathrm{kg}$ and $\mathrm{Mg}$ concentration from 2.9 to $3.8 \mathrm{mg} / \mathrm{kg}$, while the concentrations of Ca were $14.5-19 \mathrm{mg} / \mathrm{kg}$.

The selected heavy metals concentration in the four sites showed little variation in concentration because the whole area is uniformly influenced by anthropogenic activities. The one-way ANNOVA results showed that the data was non-significant. The concentration of selected metals from sites 1 to 4 were used to derive the enrichment factor, geo-accumulation index, pollution load index, modified degree of contamination, and potential ecological risk in order to assess sediment contamination. Average shale values of heavy metals were used as background reference values taken from uncontaminated sites, and their use helps to evaluate heavy metal enrichment whether from natural or anthropogenic sources.

Heavy metals at all sites showed enrichment factor (EF) values $<1$, suggesting that the heavy metals were not significantly enriched from human activities and the selected sites were unpolluted from $\mathrm{Cu}, \mathrm{Mn}, \mathrm{Zn}, \mathrm{Fe}$, $\mathrm{Mg}$, and $\mathrm{Ca}$. The contamination factor values were also calculated. The contamination factor (CF) values of the heavy metals were also all $<1$ except for $\mathrm{Fe}$, which showed a contamination factor value of 214.136, demonstrating that the contamination of Fe may be influenced by human activity. $\mathrm{CF}$ values of $\mathrm{Cu}, \mathrm{Zn}, \mathrm{Mn}, \mathrm{Mg}$, and $\mathrm{Ca}$ suggested low contamination or no contamination at all.

Human exposure to heavy metals is a concern for public health that has attracted the attention of researchers and health experts all over the world [25]. The multiple industrial, domestic, agricultural, medical, and technological applications have led to wide distribution 
Table 5. Concentrations of heavy metals and average shale values.

\begin{tabular}{|c|c|c|c|c|c|c|}
\hline Sampling Stations & $\begin{array}{c}\mathrm{Cu} \\
(\mathrm{mg} / \mathrm{kg})\end{array}$ & $\begin{array}{c}\mathrm{Zn} \\
(\mathrm{mg} / \mathrm{kg})\end{array}$ & $\begin{array}{c}\mathrm{Mn} \\
(\mathrm{mg} / \mathrm{kg})\end{array}$ & $\begin{array}{c}\mathrm{Fe} \\
(\mathrm{mg} / \mathrm{kg})\end{array}$ & $\begin{array}{c}\mathrm{Mg} \\
(\mathrm{mg} / \mathrm{kg})\end{array}$ & $\begin{array}{c}\mathrm{Ca} \\
(\mathrm{mg} / \mathrm{kg})\end{array}$ \\
\hline $\mathrm{S} 1$ & 15 & 16 & 59 & 770 & 3.2 & 14.5 \\
\hline $\mathrm{S} 2$ & 14 & 16 & 56 & 764 & 3.4 & 15.8 \\
\hline $\mathrm{S} 3$ & 13 & 16 & 57 & 762 & 3.8 & 16.00 \\
\hline $\mathrm{S} 4$ & 15 & 15 & 58 & 779 & 2.9 & 19.00 \\
\hline Average shale value & 32 & 129 & 720 & 3.59 & 21.1 & 53.6 \\
\hline
\end{tabular}

${ }^{a}$ Chakravarty and Patgiri 2009

Table 6. Calculated geoaccumulation index.

\begin{tabular}{|c|c|c|c|c|c|c|}
\hline Sample location & $\mathrm{Cu}$ & $\mathrm{Zn}$ & $\mathrm{Mn}$ & $\mathrm{Fe}$ & $\mathrm{Mg}$ & $\mathrm{Ca}$ \\
\hline $\mathrm{S} 1$ & -1.680 & -3.591 & -4.184 & 7.159 & -3.308 & -2.473 \\
\hline $\mathrm{S} 2$ & -1.775 & -3.591 & -4.265 & 7.148 & -3.224 & -2.351 \\
\hline $\mathrm{S} 3$ & -1.884 & -3.591 & -4.238 & 7.145 & -3.059 & -2.329 \\
\hline $\mathrm{S} 4$ & -1.680 & -3.680 & -4.211 & 7.175 & -3.556 & -2.065 \\
\hline
\end{tabular}

Table 7. A) Enrichment factor, B) contamination factor, and pollution load index (PLI).

\begin{tabular}{|c|c|c|c|c|c|c|c|}
\hline \multirow{2}{*}{ Sample Location } & $\mathrm{Cu}$ & $\mathrm{Zn}$ & $\mathrm{Mn}$ & $\mathrm{Fe}$ & $\mathrm{Mg}$ & $\mathrm{Ca}$ & \multirow{2}{*}{ PLI } \\
\hline & A & B & A & B & A & A & \\
\hline S1 & $0.002---0.469$ & $0.0005---0.124$ & $0.0003---0.081$ & 0---214.484 & $0.0007---0.151$ & $0.001---0.270$ & 0.598 \\
\hline S2 & $0.002---0.437$ & $0.0005---0.124$ & $0.0003---0.077$ & $0---212.813$ & $0.0008---0.161$ & $0.001---0.295$ & 0.589 \\
\hline S3 & $0.001---0.406$ & $0.0005---0.124$ & $0.0003---0.079$ & $0---212.256$ & $0.0009---0.180$ & $0.002---0.298$ & 0.597 \\
\hline S4 & $0.002---0.469$ & $0.0005---0.116$ & $0.0003---0.080$ & 0---216.991 & $0.0009---0.137$ & $0.004---0.354$ & 0.598 \\
\hline Average & $0.0055---0.445$ & $0.0005---0.151$ & 0.0003---0.0792 & $0---214.136$ & $0.0008---0.157$ & $0.002---0.304$ & 0.595 \\
\hline
\end{tabular}

of metals in the environment, raising concerns over their potential effects on human health and the environment [26]. Their toxicity depends on several factors, including the dose, route of exposure, and chemical species, as well as the age, gender, genetics, and nutritional status of exposed individuals [27, 28]. All pollution load index (PLI) values are $<1$, which suggests that all sites were less polluted and that there is no concern of ecological risk from the selected metals.

The calculated values of geo-accumulation are shown in Table 7. Igeo values confirmed contamination and enrichment factors. The values for $\mathrm{Cu}, \mathrm{Zn}, \mathrm{Mn}, \mathrm{Mg}$, and $\mathrm{Ca}$ were $<0$, declaring their concentration uncontaminated, whereas Fe showed an extremely polluted level with Igeo value of $>5$, which suggests that the sites are highly polluted by $\mathrm{Fe}$. Along with this, the modified degree of contamination values are also in agreement with pollution load index. The $\mathrm{mCd}$ values for $\mathrm{Cu}$ and $\mathrm{Zn}$ are 0.596 . This value is $<1.5$ and comes in a class of nil or very low degree of contamination.
It is a well-established fact that heavy metals can be transferred from the topsoil to the other components of the environment like groundwater or crops, and may enter into the food chain through irrigation practices. Metals can cause serious health risks to consumers by intake of the contaminated food crops if these metals exceed the permissible limits [29-30]. The potential ecological risk index (RI) is calculated only for $\mathrm{Cu}$ and $\mathrm{Zn}$ because toxic risk factors of the Hakanson model are only for these two metals among the selected metals. The RI index value for these two metals was 2.376. This value declared that there is low ecological risk from these two metals.

The spatial-temporal changing characteristics and potential ecological risk combined with local policies and industrial status were analyzed. The metal contamination was studied by sediment quality guidelines (SQGs), potential ecological risk index (PERI), and geo-accumulation index ( $\mathrm{I}_{\text {geo }}$ ) of metals $(\mathrm{Hg}, \mathrm{Cr}, \mathrm{Cd}, \mathrm{As}, \mathrm{Pb}$, and $\mathrm{Cu})$ in the sediments of the 
Xiaoqing River in Jinan [31]. The assessment suggested that $\mathrm{Hg}$ presented the highest levels of $\mathrm{I}_{\text {geo }}$ and was the largest contributor to RI, while $\mathrm{Cd}$ was the second contributor. This finding indicated that $\mathrm{Hg}$ and $\mathrm{Cd}$ had a strong effect on potential ecological risk. But it needs long-term effective management measures and a strengthened source control. The suggestions of targeted management have been proposed [31]. Similarly Fang et al., [32] argued that analyzed metals of sediment and aquatic organisms can provide important information on the environmental contamination and potential impact of aquatic food consumption. Thus, the concentrations of $\mathrm{Cu}, \mathrm{Pb}, \mathrm{Zn}, \mathrm{Cr}, \mathrm{Cd}, \mathrm{As}$, and $\mathrm{Hg}$ in sediments and fish from Chaohu Lake were analyzed with inductively coupled plasma mass spectrometry and atomic fluorescence spectrometry. The ecological risk evaluation showed that the metals in sediments posed low to medium risk. The health risk assessment suggested that the consumption of fish from Chaohu Lake is currently safe with respect to the metals. A study by Zhang et al. [33] suggested that $\mathrm{Cd}$ was the most prominent metal in the exchangeable and carbonateincluded fraction. $\mathrm{Cd}$ posed the greatest potential ecological risk.

Finally, there are also many algal communities such as Cladophora glomerata $\mathrm{L}$. in this region that can have interrelated with water and sediment qualities. The sensitivity of algal species renders them good biological indicators of water pollution. It has been pointed out that algal communities possessed many attributes as biological indicators of spatial and temporal environmental changes. Algal parameters, especially the community structural and functional variables that have been used in biological monitoring programs have been reviewed by Ebadi and Hisoriev [34].

\section{Conclusions}

The current study showed that various sites of the Farah Abad region received no or less input of heavy metals, except that $\mathrm{Fe}$ showed a high contamination factor and geo-accumulation index indicated high anthropogenic inputs of metals. This has also been confirmed by modified degree of contamination. The potential ecological risk index for $\mathrm{Cu}$ and $\mathrm{Zn}$ indicated that the selected sites were at low ecological risk for the accumulation of trace metals.

\section{Acknowledgements}

The authors greatly acknowledge the Tavakkol laboratory staff (Sari City of Iran) who carried out metal analyses for the current study.

\section{References}

1. SUNDARARAJAN S., KHADANGA M.K., KUMAR J.P.P.J., RAGHUMARAN S., VIJAYA R., JENA B.K. Ecological risk assessment of trace metal accumulation in sediments of Veraval Harbor, Gujarat, Arabian Sea. Marine Pollution Bulletin 114, 592, 2017.

2. EBADI A., SHOKRZADEH M. A survey and measurement of residues of lindane (organochlorine pesticides) in four species of the most consumed fish in the Caspian Sea (Iran). Toxicology and industrial health 22, 53, 2006.

3. KHODAMI S., SURIF M., WO W.M., DARYANABARD R. Assessment of heavy metal pollution in surface sediments of the Bayan Lepas area, Penang, Malaysia. Marine Pollution Bulletin 114, 615, 2017.

4. PEJMAN A., BIDHENDI G.N., ARDESTANI M., SAEEDI M., BAGHVAND A. A new index for assessing heavy metals contamination in sediments: A case study. Ecological Indicators 58, 365, 2015.

5. LI H., YE S., YE J., FAN J., GAO M., GUO H. Baseline survey of sediments and marine organisms in Liaohe Estuary: Heavy metals, polychlorinated biphenyls and organochlorine pesticides. Marine Pollution Bulletin 114, $555,2017$.

6. RAHMAN M.S., SAHA N., MOLLA A.H., AL-REZA S.M. Assessment of anthropogenic influence on heavy metals contamination in the aquatic ecosystem components: water, sediment, and fish. Soil and Sediment Contamination: An International Journal 23, 353, 2014.

7. LI C., SUN M., SONG C., TAO P., YIN Y., SHAO M. Assessment of Heavy Metal Contamination in the Sediments of the Shuangtaizi Estuary Using Multivariate Statistical Techniques. Soil and Sediment Contamination: An International Journal 2016.

8. TURNER A. Heavy metals, metalloids and other hazardous elements in marine plastic litter. Marine Pollution Bulletin 111, 136, 2016.

9. ZHAO G., LU Q., YE S., YUAN H., DING X., WANG J. Assessment of heavy metal contamination in surface sediments of the west Guangdong coastal region, China. Marine pollution bulletin 2016.

10. ZHOU C., VITIELlO V., PELleGRINI D., WU C., MORELLI E., BUTTINO I. Toxicological effects of $\mathrm{CdSe} / \mathrm{ZnS}$ quantum dots on marine planktonic organisms. Ecotoxicology and environmental safety 123, 26, 2016.

11. DADAR M., ADEL M., FERRANTE M., NASROLLAHZADEH SARAVI H., COPAT C., OLIVERI CONTI G. Potential risk assessment of trace metals accumulation in food, water and edible tissue of rainbow trout (Oncorhynchus mykiss) farmed in Haraz River, northern Iran. Toxin Reviews 35, 141, 2016.

12. EL AZHARI A., RHOUJJATI A., HACHIMI M.L.E. Assessment of heavy metals and arsenic contamination in the sediments of the Moulouya River and the Hassan II Dam downstream of the abandoned mine Zeïda (High Moulouya, Morocco). Journal of African Earth Sciences 119, 279, 2016

13. DONG C.D., CHEN C.F., JU Y.R., CHEN C.W. Metal pollution and ecological risk assessment in the surface sediments of Anping Harbor, Taiwan. Desalination and Water Treatment 57, 29274, 2016. 
14. MACDONALD D.D., INGERSOLL C.G., BERGER T. Development and evaluation of consensus-based sediment quality guidelines for freshwater ecosystems. Archives of environmental contamination and toxicology 39, 20, 2000.

15. SWARTZ R.C. Consensus sediment quality guidelines for polycyclic aromatic hydrocarbon mixtures. Environmental Toxicology and Chemistry 18, 780, 1999.

16. ABRAHIM G., PARKER R. Assessment of heavy metal enrichment factors and the degree of contamination in marine sediments from Tamaki Estuary, Auckland, New Zealand. Environmental Monitoring and Assessment 136, 227, 2008.

17. HAKANSON L. An ecological risk index for aquatic pollution control. A sedimentological approach. Water research 14, 975, 1980.

18. TOMLINSON D., WILSON J., HARRIS C., JEFFREY D. Problems in the assessment of heavymetal levels in estuaries and the formation of a pollution index. Helgol Mar Res 33, 566, 1980.

19. KALANTARI M., EBADI A. Measurement of Some Heavy Metals in Sediments from Two Great Rivers (Tajan and Neka) of Iran. Journal of Applied Sciences 6, 1071, 2006.

20. KALANTARI M., EBADI A. Geochemical assessment of some heavy metal levels in Neka river sediments-Neka city, Iran. 2006.

21. EL-SAID G.F., DRAZ S.E., EL-SADAAWY M.M., MONEER A.A. Sedimentology, geochemistry, pollution status and ecological risk assessment of some heavy metals in surficial sediments of an Egyptian lagoon connecting to the Mediterranean Sea. Journal of Environmental Science and Health, Part A 49, 1029, 2014.

22. KIMBROUGH K., LAUENSTEIN G. Major and trace element analytical methods of the National Status and Trends Program: 2000-2006. 2007.

23. CHAKRAVARTY M., PATGIRI A.D. Metal pollution assessment in sediments of the Dikrong River, NE India. J Hum Ecol 27, 63, 2009.

24. ARMSTRONG R., TAYLOR S., TARNEY J. The Composition and Evolution of the Continental Crust: Rare Earth Element Evidence from Sedimentary Rocks: Discussion. Philosophical Transactions of the Royal Society of London Series A 301, 398, 1981.

25. OTITOJU O., AKPANABIATU M., OTITOJU G., NDEM J., UWAH A., AKPANYUNG E., et al. Heavy metal contamination of green leafy vegetable Gardens in Itam Road Construction site in Uyo, Nigeria. Research journal of environmental and earth sciences 4, 371, 2012.

26. SALEEM M., IQBAL J., SHAH M.H. Spatio-Temporal Variability and Pollution Assessment of Selected Metals in Freshwater Sediments, Pakistan. CLEAN-Soil, Air, Water 2016.

27. TCHOUNWOU P.B., YEDJOU C.G., PATLOLLA A.K., SUTTON D.J. Heavy metal toxicity and the environment. Molecular, clinical and environmental toxicology: Springer; 133, 2012.

28. DAVIS H.T., AELION C.M., MCDERMOTT S., LAWSON A.B. (Identifying natural and anthropogenic sources of metals in urban and rural soils using GIS-based data, PCA, and spatial interpolation. Environmental Pollution, 157 (8), 2378, 2009.

29. LIAO Q.L., LIU C., WU H.Y., JIN Y., HUA M., ZHU B.W., et al. Association of soil cadmium contamination with ceramic industry: A case study in a Chinese town. Science of The Total Environment 514, 26, 2015.

30. ZHAO Q., WANG Y., CAO Y., CHEN A., REN M., GE Y., et al. Potential health risks of heavy metals in cultivated topsoil and grain, including correlations with human primary liver, lung and gastric cancer, in Anhui province, Eastern China. Science of the Total Environment 470, 340, 2014.

31. JIAOF., REN L., WANG X., LIU W. Pollution characteristics and potential ecological risk assessment of metals in the sediments of Xiaoqing River, Jinan. Environmental Science and Pollution Research 1, 2017.

32. FANG T., LU W., LI J., ZHAO X., YANG K. Levels and risk assessment of metals in sediment and fish from Chaohu Lake, Anhui Province, China. Environmental Science and Pollution Research 1, 2017.

33. ZHANG L., LIAO Q., SHAO S., ZHANG N., SHEN Q., LIU C. Heavy metal pollution, fractionation, and potential ecological risks in sediments from Lake Chaohu (Eastern China) and the surrounding rivers. International journal of environmental research and public health 12, 14115, 2015.

34. EBADI A.G., HIKMAT H. The prevalence of heavy metals in Cladophora glomerata L. from Farahabad Region of Caspian Sea - Iran. Toxicological and Environmental Chemistry 99, 883, 2017. 